\title{
RESULTS OF GEOPHYSICAL SURVEYS OF GLACIAL DEPOSITS NEAR A FORMER WASTE- DISPOSAL SITE, NASHUA, NEW HAMPSHIRE
}

By Joseph D. Ayotte and Tracy H. Dorgan

U.S. GEOLOGICAL SURVEY

Open-File Report 95-142

Prepared in cooperation with the

U.S. ENVIRONMENTAL PROTECTION AGENCY

REGION I

Bow, New Hampshire

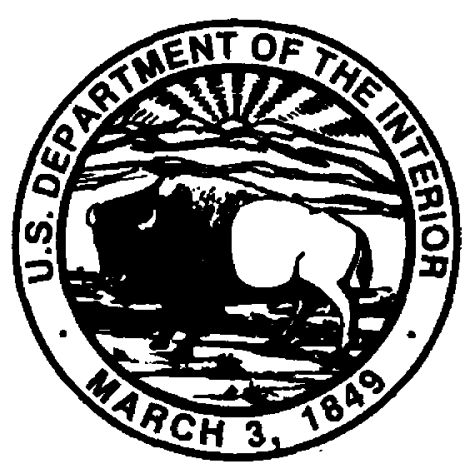

1995 


\title{
U.S. DEPARTMENT OF THE INTERIOR BRUCE BABBITT, Secretary
}

\author{
U.S. GEOLOGICAL SURVEY \\ Gordon P. Eaton, Director
}

For additional information write to:

Chief, New Hampshire-Vermont District

U.S. Geological Survey

525 Clinton Street

Bow, NH 03304
Copies of this report can be purchased from:

U.S. Geological Survey

Earth Science Information Center

Open-File Reports Section

Box 25286, MS 517

Denver Federal Center

Denver, CO 80225 


\section{CONTENTS}

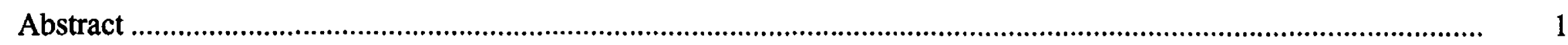

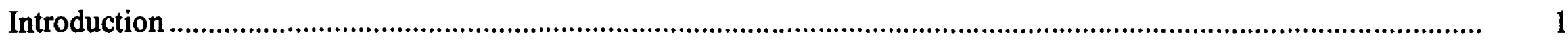

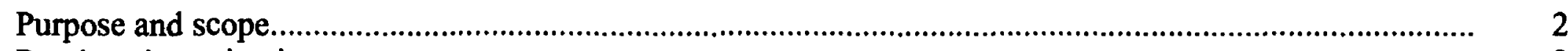

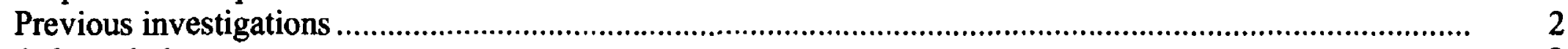

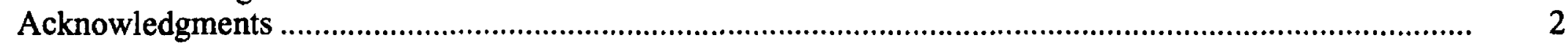

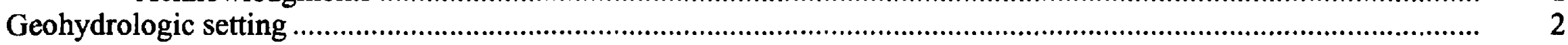

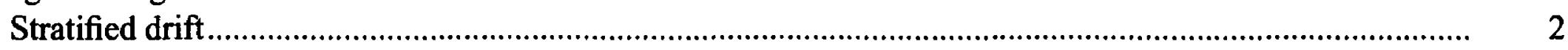

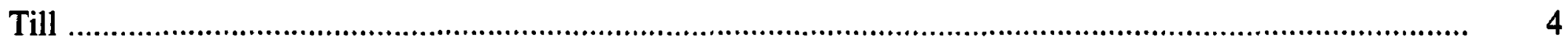

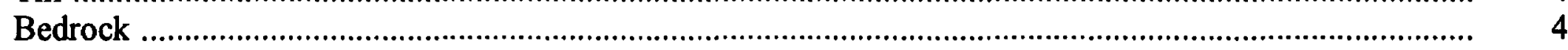

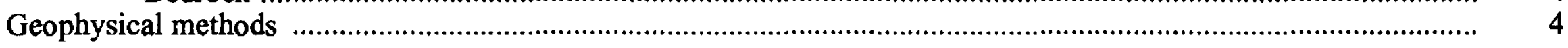

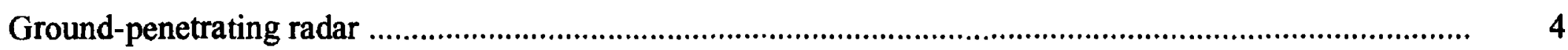

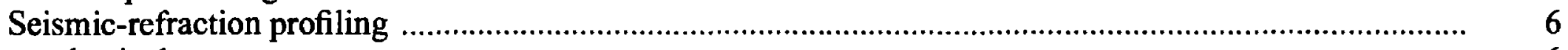

Results of geophysical surveys

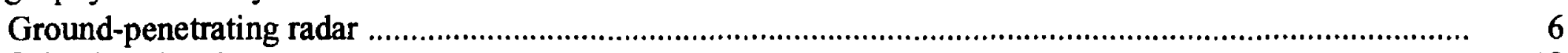

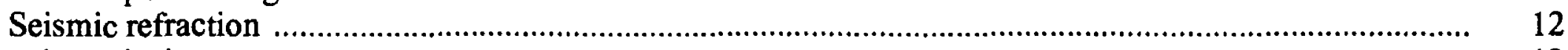

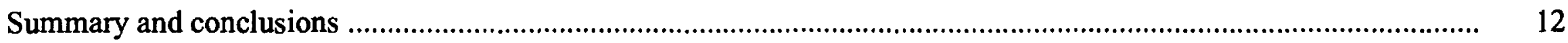

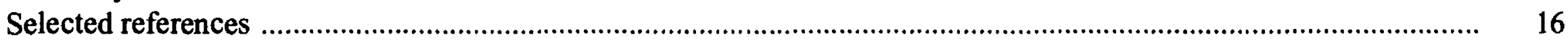

\section{ILLUSTRATIONS}

Figure1. Map showing locations of ground-penetrating radar profiles, test borings, and observation wells, Nashua, New Hampshire

2. Map showing locations of seismic-refraction profiles, test borings, and observation wells, Nashua, New Hampshire

3-6. Unprocessed ground-penetrating radar profiles, Nashua, New Hampshire:
3. $\mathrm{A}-\mathrm{A}^{\prime}$
4. B-B'
5. C-C'.
6. D-D'.

7-8. Geohydrologic sections interpreted from seismic-refraction data for profiles:

7. $a-a^{\prime}, b-b^{\prime}$, and $c-c^{\prime}$

8. $d-d^{\prime}$ and $e-e^{~}$

\section{TABLES}

1. Lithologic logs of selected wells and borings, Nashua, New Hampshire 


\begin{tabular}{rlll} 
Mulliply & By & To Oblain \\
\hline inch (in) & 25.4 & millimeter \\
foot (ft) & 0.3048 & meter \\
mile (mi) & 1.609 & kilometer \\
foot per nanosecond (ft/ns) & 0.3048 & meters per nanosecond \\
square mile (mi $\left.{ }^{2}\right)$ & 2.59 & square kilometer \\
gallon per minute $(\mathrm{gal} / \mathrm{min})$ & 0.06308 & liter per second
\end{tabular}

Sea Level: In this report "sea level" refers to the National Geodetic Vertical Datum of 1929 (NGVD of 1929)--a geodetic datum derived from a general adjustment of the first-order level nets of both the United States and Canada, formerly called Sea Level Datum of 1929.inch

In this report, 1 nanosecond (ns) is equal to $10^{-9}$ seconds. 


\title{
RESULTS OF GEOPHYSICAL SURVEYS OF GLACIAL DEPOSITS NEAR A FORMER WASTE-DISPOSAL SITE, NASHUA, NEW HAMPSHIRE
}

\author{
By Joseph D. Ayotte and Tracy H. Dorgan
}

\begin{abstract}
Geophysical investigations were done near a former waste-disposal site in Nashua, New Hampshire, to determine the thickness and infer hydraulic characteristics of the glacial sediments that underlie the area. Data will be used to help define the ground-water-flow system near the Gilson Road Comprehensive Environmental Response, Compensation, and Liability Act site.
\end{abstract}

Approximately 5 miles of ground-penetrating radar (GPR) data were collected in the study area by use of dual 80 -megahertz antennas. Three distinct radar-reflection signatures were evident from the data and are interpreted to represent (1) fine-grained glacial lake sediments, (2) coarse sand and gravel and (or) glacial till, and (3) bedrock. The GPR signal penetrated as much as 70 feet of sediment in coarse-grained areas, but penetration depth was generally less than 40 feet in extensive areas of fine-grained lacustrine deposits. Geologic features were evident in many of the profiles. Fine-grained lacustrine deposits were the most common of the three types of deposits identified. Other features include deltas deposited in glacial Lake Nashua and lobate fans of sediment deposited subaqueously at the distal end of deltaic sediments. Cross-bedded sands were commonly identifiable in the deltaic sediments.

Seismic-refraction data also were collected at five of the GPR data sites. In most cases, depths to the water table and to the till and (or) bedrock sur- face indicated by the seismic-refraction data compared favorably with depths calculated from the GPR data.

Test holes were drilled at three locations to confirm depths to radar reflectors and to determine the types of geologic material represented by the various reflector types. Observation wells were installed at three of the sites so that periodic waterlevel measurements could be made.

\section{INTRODUCTION}

During the 1960's and 1970's, various waste products, including hazardous materials, were disposed of at a site on Gilson Road in Nashua, N.H. (fig. 1). The State of New Hampshire received a U.S. Environmental Protection Agency grant in 1981 to remediate the site; since then, many ground-water investigations have been done. Most of these investigations have concentrated on the areas in the immediate vicinity of the disposal site. In 1981, water from domestic wells downgradient from the Gilson Road site was found to be contaminated with volatile organic compounds and other hazardous chemicals (Weston, 1989). The site is currently (1994) undergoing remediation under the authority of the Comprehensive Environmental Response, Compensation, and Liability Act (CERCLA) of 1980. Much of the population within the study area is served by a privately owned community water system; therefore, geohydrologic data from drilled wells outside of the hazardous-waste site are sparse. Efforts are presently focusing on the ground-water-flow system outside the immediate area of contamination. As part of these efforts, a study was done by the U.S. Geological 
Survey, in cooperation with the U.S. Environmental Protection Agency, to provide hydrogeologic information for ongoing and future remediation activities at this site. In addition, efforts to construct a ground-water-flow model of the site have resulted in a need to examine the geohydrology of the stratified-drift deposits at and near the site.

\section{Purpose and Scope}

This report presents the results of geophysical investigations over glacial stratified drift near the Gilson Road waste-disposal facility and in the vicinity of Lyle Reed Brook near its confluence with the Nashua River. Included in the report are geophysical profiles that provide information about the various lithologies and, in some locations, depths to bedrock. Test-boring data also are presented in the report and were used to confirm the results of the geophysical surveys. The investigation was limited to the $1-\mathrm{mi}^{2}$ area bounded by Gilson Road, Countryside Drive, the Nashua River, and Jensens River Pines trailer park (fig. 1).

\section{Previous Investigations}

The surficial geology of the Pepperell Quadrangle, in which the study area is located, was mapped at a scale of 1:24,000 by Koteff and Volckmann (1973). That map report describes the various levels of glacial Lake Nashua and associated deposits. Toppin (1987) describes the hydrogeology of the area as part of a regional study to map the stratified-drift aquifers and determine their hydraulic properties. In conjunction with the site-remediation activities, numerous hydrogeologic studies have been done since 1980 by private consultants, and several studies have been done by State and Federal agencies; a review of these can be found in Weston (1989). Previous studies, however, have focused primarily on the areas within or near the main area of contamination.

\section{Acknowledgments}

We thank the many private landowners who allowed us access to their land during this investigation. In addition, we thank the private consulting firms who supplied additional data used for this study, and officials of the city of Nashua for their cooperation.

\section{GEOHYDROLOGIC SETIING}

Ground water flows through three geohydrologic units in the study area. These geohydrologic units are (1) stratified drift, the uppermost aquifer unit, which stores and transmits the largest quantities of water; (2) till, a discontinuous layer between the stratified drift and the bedrock surface that transmits only minor amounts of water; and (3) bedrock, which transmits variable amounts of water primarily through fractures.

\section{Stratified Driff}

The waste-disposal site and surrounding area.are underlain by a stratified-drift aquifer composed of glaciofluvial sands and gravels and glaciolacustrine fine sands and silt that were deposited in and near glacial Lake Nashua (Koteff and Volckmann, 1973). This glacial lake formed between the till and (or) bedrock uplands to the south and the retreating ice margin to the northeast. Because preglacial drainage was to the northeast, retreating ice uncovered successively lower outlets or spillways through which the glacial lake drained. Glacial Lake Nashua lowered in six successive stages (Koteff and Volckmann, 1973), and the deposits in the study area consist of sands and gravels associated with stages 4 and 5 .

Coarse-grained deposits associated with stage 4 of glacial Lake Nashua are present along Trout Brook Drive and near Gilson Road to the south. These deposits are partly covered by fine-grained glacial-lake-bottom deposits. Stage 4 deposits are graded to a spillway at an elevation of approximately $215 \mathrm{ft}$ above sea level (Koteff and Volckmann, 1973). Along Trout Brook Drive, an esker that is noticeable on the surficial geologic map of the Pepperell Quadrangle has since been removed by excavation. Well NAW-220, constructed for Pennichuck Water Works in 1969 and located near the eastern edge of the coarse-grained deposit, was screened in coarse-grained deposits 48 to $68 \mathrm{ft}$ below land surface. The superimposition of glacial-lake-bottom sediments over the coarse material indicates that the esker is partly buried by fine-grained deposits from a later glacial lake stage (stage 5). Well NAW-220 was tested at more than $1,100 \mathrm{gal} / \mathrm{min}$. 


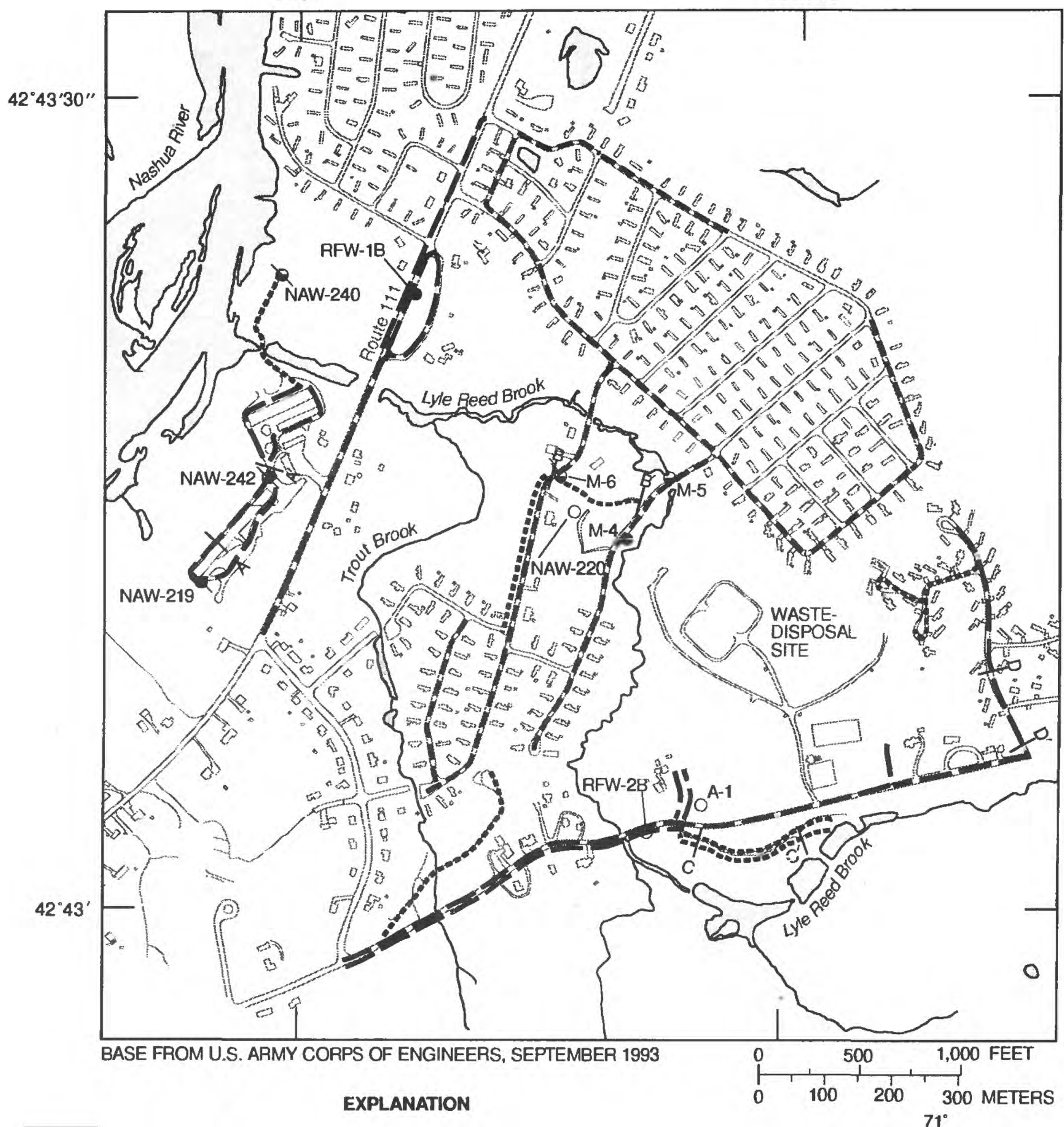

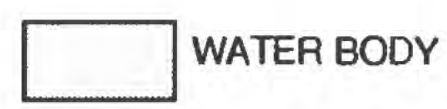

GROUND-PENETRATING RADAR
PROFILES

- $=-m / 18 / 93$

$--5 / 20 / 93$

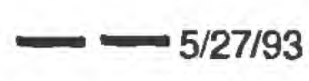

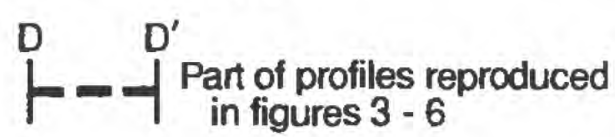

TEST WELS AND BORINGS
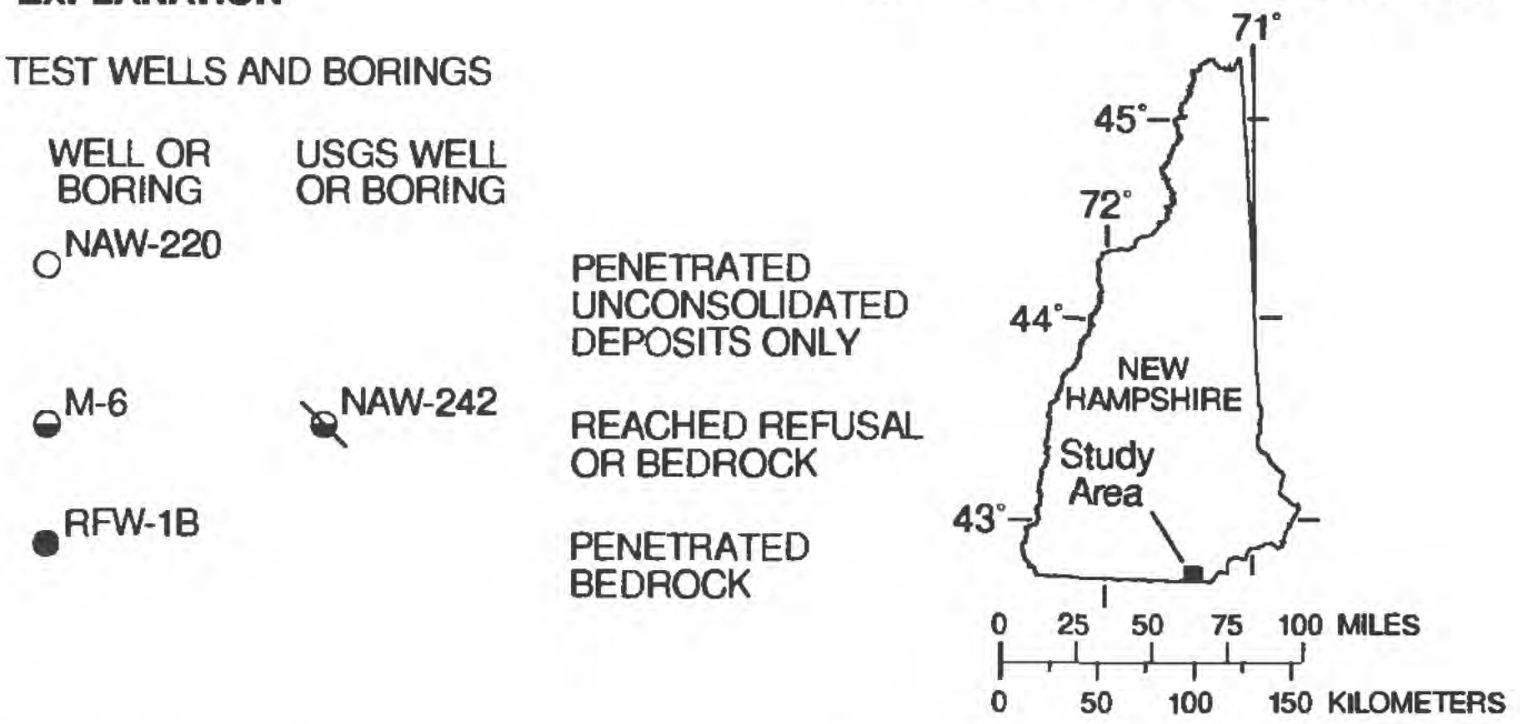

Figure 1. Locations of ground-penetrating radar profiles, test borings, and observation wells, Nashua, New Hampshire. 
Deposits associated with stage 5 are limited to a small area near Jensens River Pines trailer park. These deposits are graded to the next stage of Glacial Lake Nashua, which was approximately $10 \mathrm{ft}$ lower than stage 4, and they include sands and gravels.

Fine-grained lake-bottom deposits are present throughout most of the study area and, in places, overlie or are in contact with coarse-grained deposits. Koteff and Volckmann (1973) identify glacial-lake-bottom sediments at land surface near Gilson Road. Logs from test holes drilled for previous studies indicate that fine-grained lake-bottom deposits are extensive and underlie much of the stream-terrace deposits along the Nashua River near its confluence with Lyle Reed Brook (table 1). Very fine to medium sands are 20 to $30 \mathrm{ft}$ below land surface at well NAW-240. Till underlies these sands.

Stream-terrace deposits are present mainly from the Nashua River east to Trout Brook Drive. Recent alluvium is present primarily along the Nashua River and is not areally extensive in the study area.

\section{Till}

Till is an unsorted mixture of clay, silt, sand, and rock fragments with variable composition and degree of compactness. Two distinct tills have been recognized in this region and are thought to represent two separate ice advances over the region (Koteff, 1976; Koteff and Volckmann, 1973). The lower till is fairly compact and oxidized, whereas the upper till is generally sandy and unoxidized. Till is rarely exposed in the study area but discontinuously underlies the stratified deposits. Lithologic samples from test drilling done for this study (wells NAW-240, NAW-241, and NAA-219) included only a sandy till.

\section{Bedrock}

The bedrock underlying most of the study area is composed of schists and phyllites of the Merrimack Group and is similar to the rocks of the Berwick Formation (Lyons and others, 1986). Previous studies, summarized by Weston (1989), have indicated that the bedrock surface in the study area is highly fractured. This fracturing indicates that the secondary permeability of the bedrock is significant and that a measurable amount of ground water may flow between the upper part of the bedrock and the overlying till and (or) stratified drift.

\section{GEOPHYSICAL METHODS}

Ground-penetrating radar (GPR) and seismic refraction were used to investigate the geohydrology of the glacial deposits in the study area. Both methods provide a nearly continuous profile of the subsurface. For this study, seismic-refraction data were collected to provide continuous profiles of the water-table surface and the till and (or) bedrock surface. GPR provides greater resolution and detail relative to the stratigraphy and physical properties of the subsurface deposits than seismic refraction. For this study, depths to reflectors and types of lithologies were verified by comparing depths to reflectors with depths to lithologic units inferred from well and test-boring logs.

\section{Ground-Penetrating Radar}

GPR surveys were done according to methods described by Beres and Haeni (1991) at the survey locations shown in figure 1. The GPR-survey system transmits radio-frequency electromagnetic pulses into the ground and receives energy reflected back from subsurface reflectors. Reflectors can be any subsurface contact between geologic materials with different physical and electrical properties, such as the interface between lithologic units or layers within a unit. The surveys were conducted with dual $80 \mathrm{MHz}$ (megahertz) center-frequency transmitting and receiving antennas that were towed at approximately $75 \mathrm{ft}$ behind a vehicle. The profiles can be examined visually to provide indications of lithologic properties. Analysis of GPR profiles are improved by the use of additional geophysical data and (or) lithologic logs acquired during test drilling.

Beres and Haeni (1991) provide an interpretation guide for various types of reflection configurations for unconsolidated deposits. Parallel reflectors indicate the presence of laminated fine-grained sediments, such as glacial-lake-bottom sediments. Complex, subparallel, and chaotic reflectors may indicate coarse-grained sediments and may give evidence as to the depositional environment. Inverted V-shaped reflectors probably 
Table 1. Lithologic logs for selected wells and borings, Nashua, New Hampshire [--, no data]

\begin{tabular}{|c|c|c|c|}
\hline $\begin{array}{l}\text { Well or boring } \\
\text { identifier }\end{array}$ & $\begin{array}{l}\text { Depth to } \\
\text { top } \\
\text { (feet) }\end{array}$ & $\begin{array}{l}\text { Depth to } \\
\text { bottom } \\
\text { (feet) }\end{array}$ & Lithology \\
\hline \multirow[t]{3}{*}{ NAA-219 } & 0 & 7 & Sand, fine to very fine; few pebbles \\
\hline & 7 & 16 & Till; sandy and silty; few pebbles and cored cobbles \\
\hline & 16 & -- & Firm refusal; probably bedrock \\
\hline \multirow[t]{4}{*}{ NAW-220 } & 0 & 30 & Sand, fine, brown \\
\hline & 30 & 48 & Sand, fine to medium \\
\hline & 48 & 50 & Sand, coarse and medium gravel \\
\hline & 50 & - & Gravel, coarse, end at 67.5 feet \\
\hline \multirow[t]{5}{*}{ NAW-240 } & 0 & 10 & Sand, very fine to fine, tan; coarser with depth \\
\hline & 10 & 21 & Sand, medium to coarse, $\tan$; moderately to well sorted \\
\hline & 21 & 31 & Sand, fine with some coarser layers \\
\hline & 31 & 40 & Till; loosely compacted, mostly coarse sand \\
\hline & 40 & -- & Firm refusal; probably bedrock \\
\hline \multirow[t]{4}{*}{ NAW-242 } & 0 & 12 & Very fine sand and silt \\
\hline & 12 & 15 & Sandy till \\
\hline & 15 & 24 & Sand, very fine and silt \\
\hline & 24 & -- & Till; loosely compacted; refusal at 33.5 feet \\
\hline \multirow[t]{7}{*}{ M4 } & 0 & 8 & Fill \\
\hline & 8 & 9 & Black organic material; sand and silt \\
\hline & 9 & 39 & Sand, fine to medium \\
\hline & 39 & 49 & Sand, fine \\
\hline & 49 & 86.5 & Sand, fine and silt \\
\hline & 86.5 & 91.5 & Till \\
\hline & 91.5 & - & Bedrock; cored to 101.5 feet \\
\hline \multirow[t]{5}{*}{ M5 } & 0 & 16 & Fill \\
\hline & 16 & 49 & Sand, fine \\
\hline & 49 & 76 & Sand. fine; variable density \\
\hline & 76 & 90.5 & Sand, fine, dense; some gravel near bottom of unit \\
\hline & 90.5 & - & Till; refusal at 103.5 feet \\
\hline \multirow[t]{3}{*}{ M6 } & 0 & 9 & Sand and gravel, medium to coarse \\
\hline & 9 & 46 & Sand, fine; trace silt \\
\hline & 46 & -- & Till; refusal at 49.5 feet \\
\hline \multirow[t]{4}{*}{ Al } & 0 & 17 & Sand, fine to medium; some gravel \\
\hline & 17 & 29 & Sand, fine to medium \\
\hline & 29 & 44 & Sand, medium \\
\hline & 44 & -- & Till; end of hole at 52 feet \\
\hline \multirow[t]{3}{*}{ RFW-1B } & 0 & 5 & Sand, coarse; trace fine gravel \\
\hline & 5 & 10.5 & Sand and gravel, fine to coarse \\
\hline & 10.5 & - & Dark gray binary granite and quartz monzonite \\
\hline \multirow[t]{4}{*}{ RFW-2B } & 0 & 17 & Sand, fine, dark tan, some silt \\
\hline & 17 & 34 & Sand, fine to coarse; some gravel, little silt \\
\hline & 34 & 65 & Sand, fine to coarse; little silt; some gravel; \\
\hline & 65 & -- & Till, end of hole at 68 feet \\
\hline
\end{tabular}


indicate the presence of cobbles and boulders in till. Near-surface inverted V-shaped reflectors may indicate buried pipelines, culverts, or conduits.

Transmission velocities of the radar signal were used to interpret depth to a reflector. The velocity of electro-magnetic waves in saturated unconsolidated sediments is approximately $0.2 \mathrm{ft} / \mathrm{ns}$ and, in unsaturated unconsolidated sediments, is approximately $0.4 \mathrm{ft} / \mathrm{ns}$ (Beres and Haeni, 1991). Interpretation of a GPR profile, which includes unsaturated and saturated sediment, thus requires the use of two depth scales. For any radar frequency, the primary factor limiting depth of penetration is the electrical conductivity of the subsurface materials (Beres and Haeni, 1991); however, high frequencies are attenuated faster than low frequencies. Electrically conductive materials, such as clay minerals, limit radar-signal penetration. Dry, unconsolidated coarse-grained sediments enhance signal penetration.

Lithologic information obtained from test drilling is used to help interpret or confirm interpretations of GPR profiles. Electromagnetic reflectors could be present, for example, at a water-table surface, at a coarse to fine-grained interface, or at a bedrock surface, and all could be represented as a dark, continuous band on the GPR profile; however, a thin electrically conductive layer, such as a clay lens, also could be represented by a dark band. An extensive capillary fringe in fine-grained sediments may prevent the water table from showing as a continuous reflector; therefore, independently derived depths to the water table are needed to determine the correct depths to reflectors on the profile.

\section{Seismic-Refraction Profiling}

Seismic-refraction profiling was used to determine depths to the water table and depths to the bedrock surface. Locations of these profiles are shown in figure 2. The seismic-refraction method is based on a layered-earth model, whereby the velocity of sound varies with the lithologic characteristics of the material present and increases with depth. As sound waves travel across the boundary between layers having different velocity-propagation characteristics, some of the energy is refracted. When the angle of incidence is equal to the critical angle for the first layer, the sound energy is transmitted along the upper surface of the second layer at the speed of sound in the second layer. As the refracted sound wave travels, it continuously generates new sound waves that travel upward and are received by the geophones at the surface. The methods used in this survey are described by Haeni (1988). Each seismic profile was approximately $500 \mathrm{ft}$ long. A two-component explosive was used as a sound source, and each explosive charge was buried 2 to $4 \mathrm{ft}$ below land surface. The seismic data were collected by use of a 12-channel, signal-enhancing seismograph, and interpreted by use of a time-delay, ray-tracing computer program developed by Scott and others (1972). Lithologic data from nearby wells and test holes were used to verify the interpretations (table 1; fig. 2).

\section{RESULTS OF GEOPHYSICAL SURVEYS}

The results of the geophysical surveys presented in this section include selected GPR and seismic-refraction profiles. All original data from the surveys are filed at the U.S. Geological Survey, Water Resources Division, New Hampshire-Vermont District, in Bow, N.H.

\section{Ground-Penetrating Radar}

Ground-penetrating radar surveys were done along approximately $5 \mathrm{mi}$ of survey lines within the study area. The areas where GPR data were collected and the locations of selected profiles are shown in figure 1. These surveys helped delineate glaciolacustrine sediments in several places. In many places along the survey lines, the data were used to delineate subsurface lithologies. Places where data collection were successful were limited primarily but not entirely to unpaved surfaces and to areas where geologic materials were coarse grained or where bedrock was less than 30 to $40 \mathrm{ft}$ below land surface.

In areas where GPR data-collection efforts yielded usable data, three distinct reflector signatures are evident. The first reflector signature consists of thin, continuous, and mostly horizontal line patterns that represent fine-grained glaciolacustrine sediments. This reflector is common in most of the areas surveyed, but it is generally absent in profiles made over coarse-grained deltaic sediments.

The second reflector signature is chaotic and hummocky in places and is indicative of coarse-grained sediment. This reflector can represent coarse sand and 


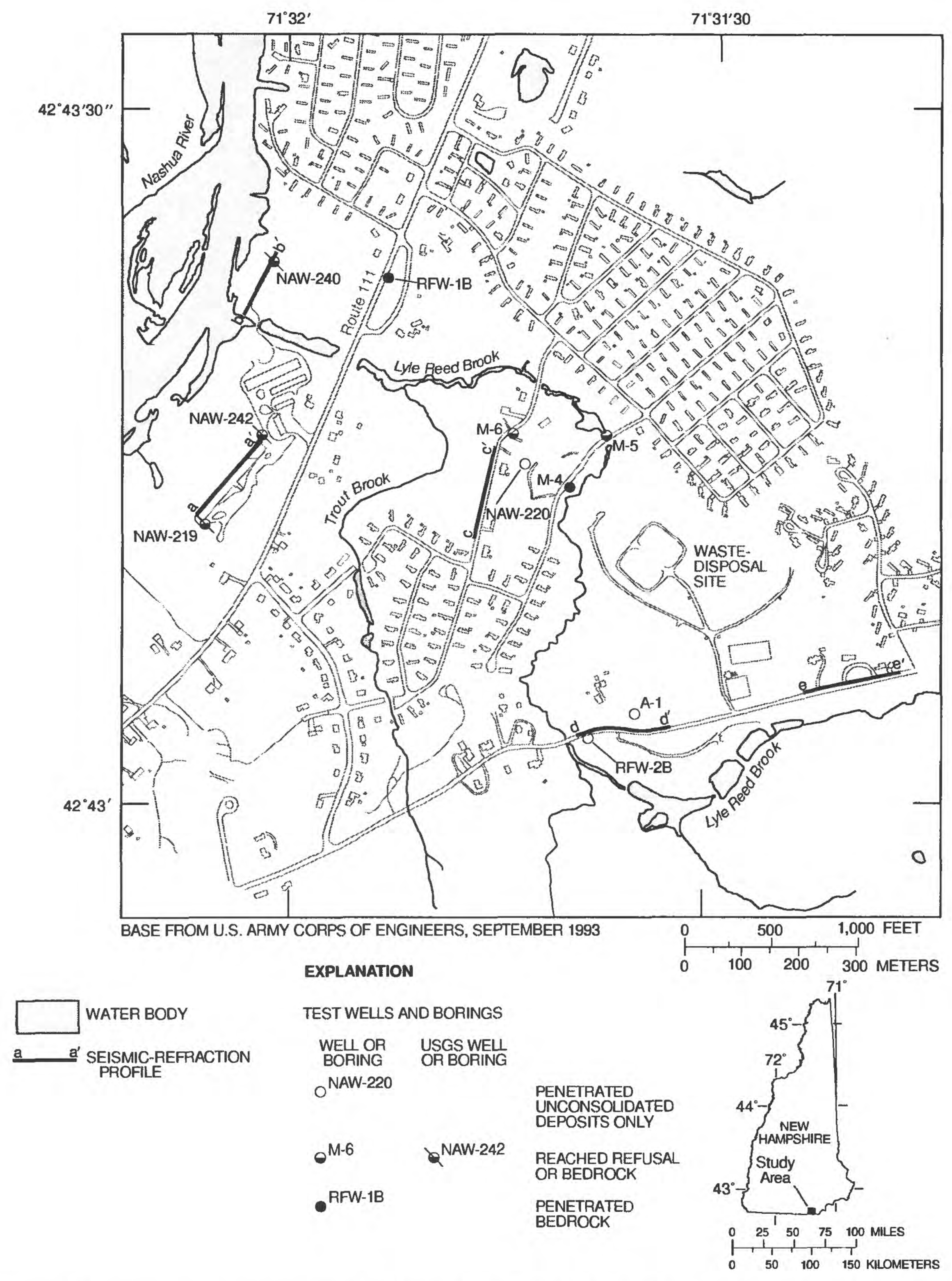

Figure 2. Locations of seismic-refraction profiles, test borings, and observation wells, Nashua, New Hampshire. 
gravel or sandy till. Where the reflection is from till, the radar record commonly contains numerous small diffraction patterns that appear as inverted V's throughout the reflector zone. The inverted V's may represent large cobbles or boulders in a till. Reflections from till in this area tend to attenuate the radar signal, probably, in part, as a result of electrically conductive clay minerals in the till.

The third reflector signature is a strong, two- to three-band reflector that is generally found beneath the other two types. This reflector is representative of the bedrock surface but, in some places, may represent a dense or electrically conductive till surface.

A reliable water-table reflector was not found on most of the profiles and, therefore, is not discussed. The lack of a well-defined water-table reflector may result from capillarity and (or) a discontinuous perched water table above the fine-grained sediments near the surface. In places, where a water-table reflector is evident, it is delineated on the profile with a dotted line.

The locations of four selected profiles are shown on figure 1. The selected profiles illustrate the three types of reflectors commonly found in the study area. These profiles and associated reflectors are described below. Test-boring data were used where available to aid in interpreting the data; some uncertainty, however, is always inherent in visual interpretations of raw GPR data.

Profile A-A' (fig. 3) is in the western part of the study area, near the Nashua River (fig. 1). The water table is not well defined on the record, probably because of the presence of a discontinuous perched water table that was detected during the drilling of test well NAW-242. Additionally, the water table is not as sharp in fine-grained stratified drift (where the capillary fringe may be several feet thick) as it is in coarse-grained stratified drift (where the capillary fringe may be only a few inches thick). Fine-grained lacustrine sediments dominate the uppermost part of the record. The surficial material in this area is mapped as stream terraces in former glaciolacustrine deposits (Koteff and Volckmann, 1973); the terraces are generally less than $10 \mathrm{ft}$ thick. The thin, parallel, mostly flat-lying reflectors in the upper part of the profile near 50 to $150 \mathrm{~ns}$ (10- to 20 -ft-depth) represent these fine-grained glaciolacustrine sands. The chaotic, sometimes hummocky reflectors near 150 to $200 \mathrm{~ns}$ (20- to 30-ft-depth on the record) represent sandy till. The log from observation well NAW-242 (table 1) shows $24 \mathrm{ft}$ of very fine sand and silt underlain by till to a depth of $33 \mathrm{ft}$. A thin (2- to 3-ft-thick) till layer approximately $12 \mathrm{ft}$ below land surface and underlain by fine sand was found during drilling; however, this feature is not resolvable on the GPR record. The thick, dark continuous band beneath the till is interpreted to be bedrock. Drilling of observation well NAW-242 was terminated, because of firm refusal, probably on bedrock, at depth of $33.5 \mathrm{ft}$.

Profile B-B' (fig. 4) is in the center of the study area (fig. 1). Most of the GPR record shows the presence of thin, flat-lying reflectors indicative of fine-grained glacial-lake-bottom sediment. The logs made at observation well M6 (table 1), on the western end of the line, show the presence of $46 \mathrm{ft}$ of fine to medium sand overlying till. The log made at test well NAW-220 (table 1), shown on the profile but approximately $100 \mathrm{ft}$ to the south, shows the presence of $48 \mathrm{ft}$ of fine to medium sand overlying approximately $20 \mathrm{ft}$ of coarse gravel. This GPR section shows loss of record at approximately 350 to $450 \mathrm{~ns}$; (35- to 45-ft-depth). This loss of record may represent the contact between the fine sands and the coarse gravel and (or) till below. This coarse-grained unit may be part of a buried esker, which is shown on the surficial geologic map of the Pepperell quadrangle (Koteff and Volckmann, 1973) several hundred feet to the west, and which has been largely removed by excavation. On the eastern part of the profile, more than $50 \mathrm{ft}$ of fine to medium sand (glaciolacustrine sediment) is identifiable. The logs from observation wells M4 (table 1), $200 \mathrm{ft}$ to the south, and M5 (table 1), $200 \mathrm{ft}$ to the north, indicate that the bedrock surface is more than $90 \mathrm{ft}$ below the land surface in this area.

Profile C-C' (fig. 5) is in the southern part of the study area, north of Lyle Reed Brook and south of the former waste-disposal facility (fig. 1). The predominantly coarse-grained sediment is the buried part of a kame delta mapped by Koteff and Volckmann (1973). The top of the strongly reflected, chaotic, and hummocky signature represents coarse sand and gravel associated with the delta. Truncated, dipping reflectors may indicate cross bedding. The distinct, lacustrine continuous reflector that represents fine-grained sediment. The second reflector signature is a chaotic, locally hummocky reflector indicative of 


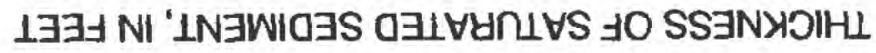
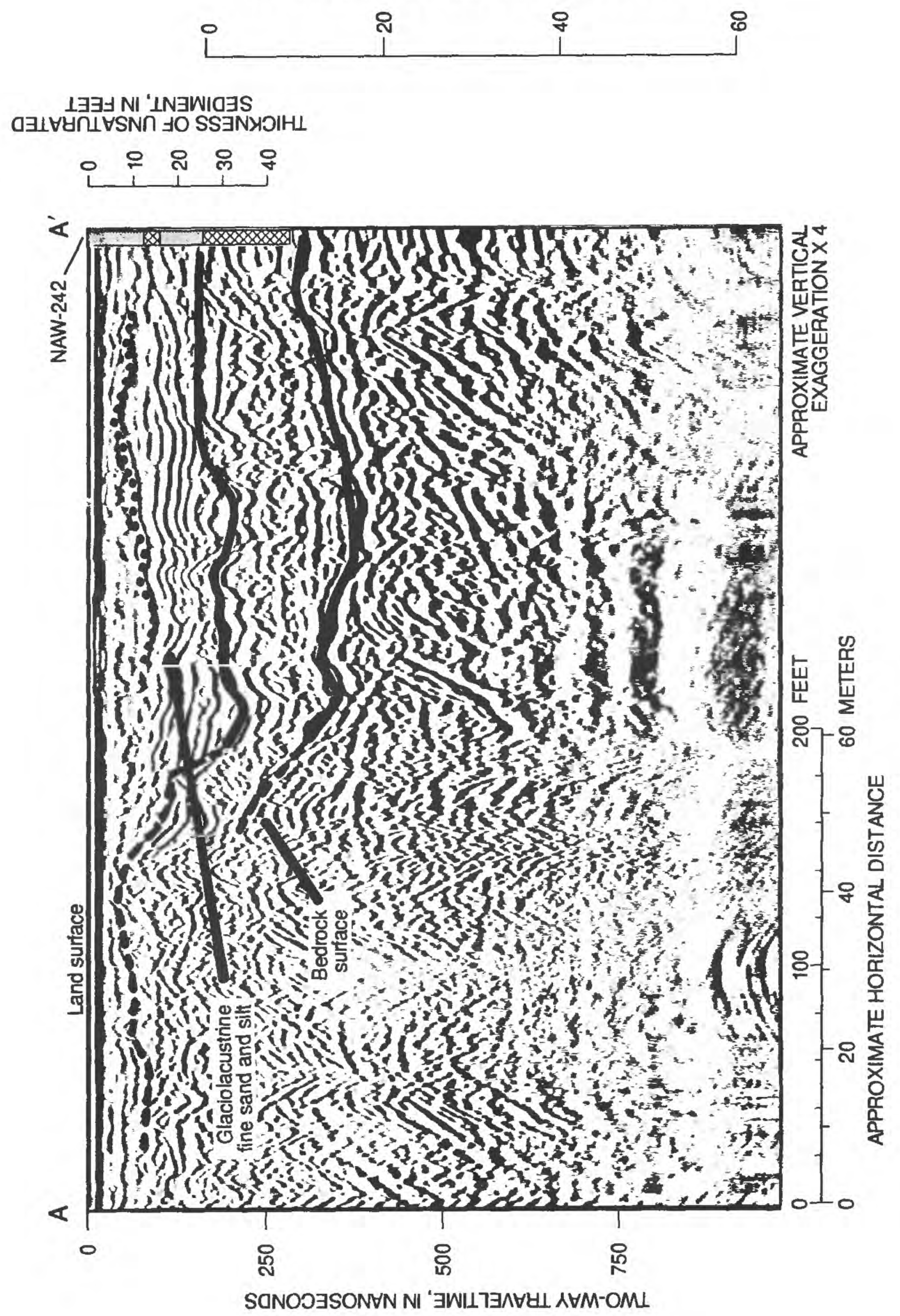

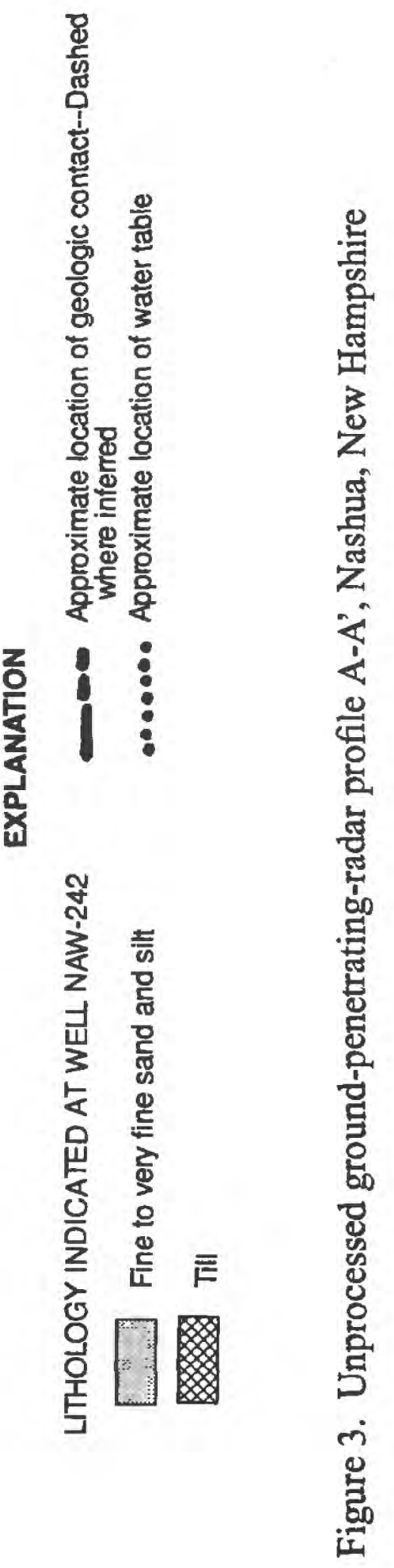



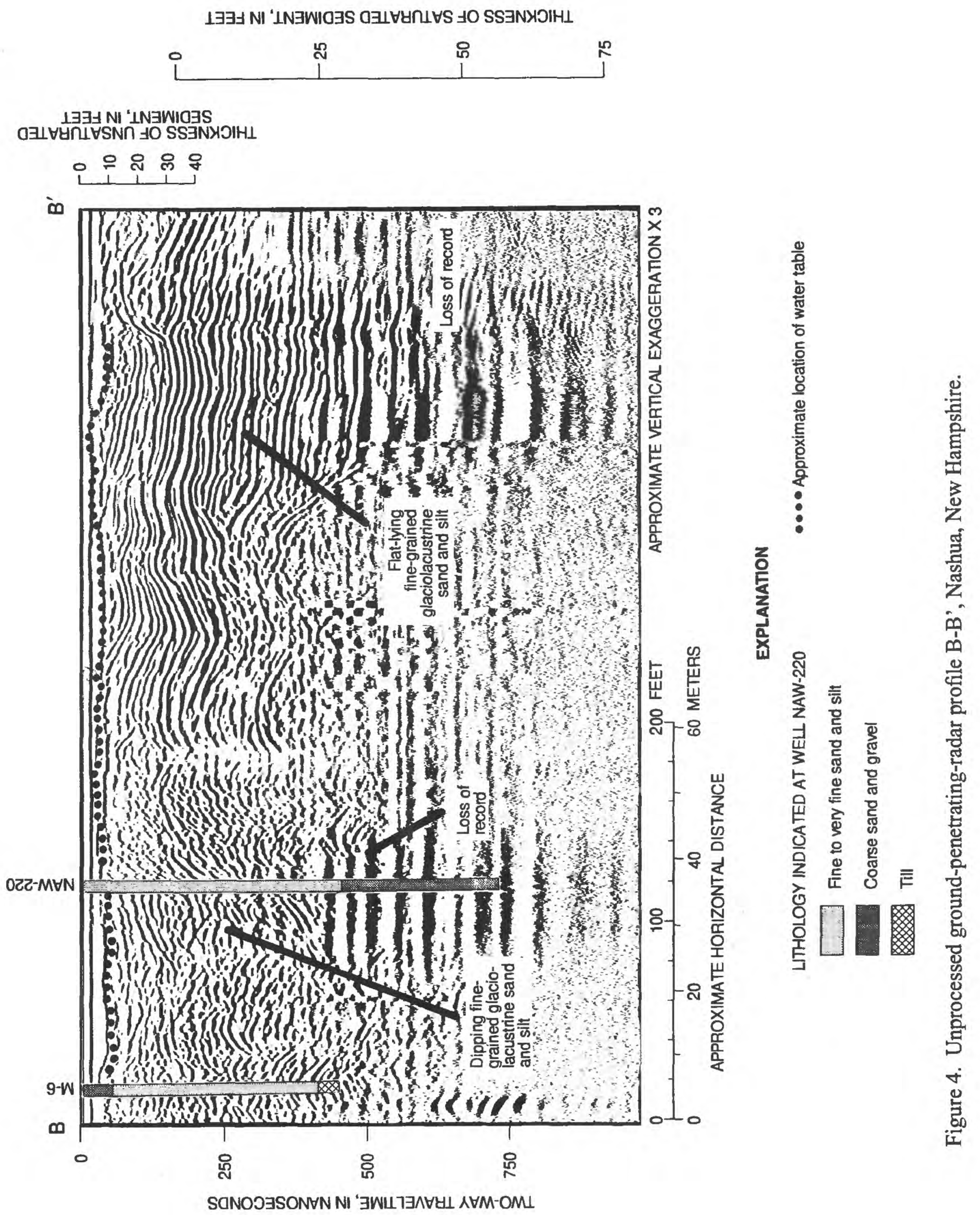


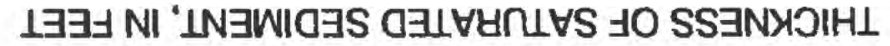
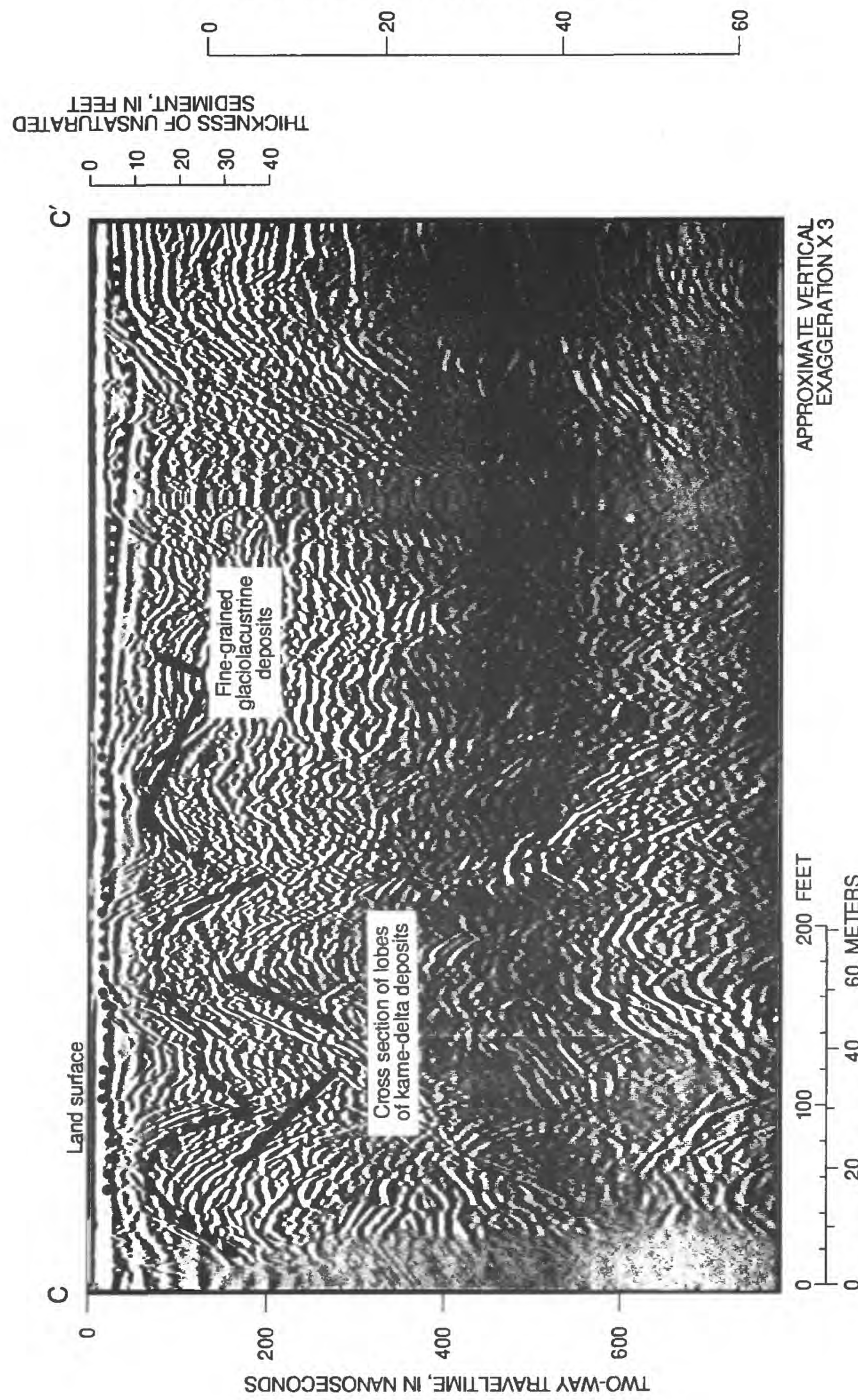

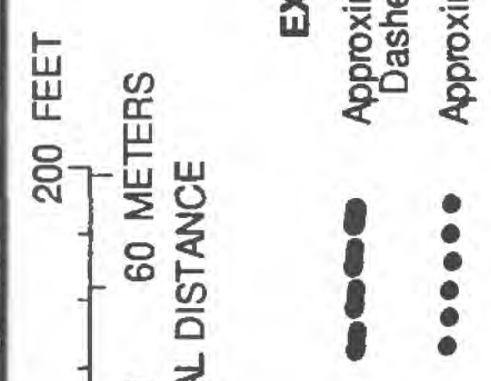

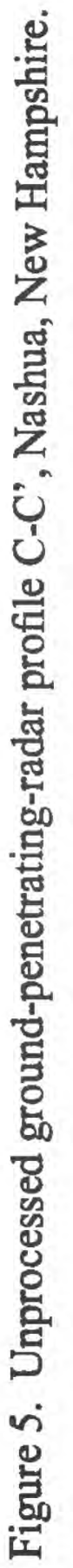


concave-upward structures visible in the profile may depict lobes of the delta as it built southward into the stage 4 level of glacial Lake Nashua. The low parts of these lobes are covered by flat-lying, continuous reflectors that appear to indicate the presence of fine-grained glaciolacustrine sediment (Ayotte, 1994).

Profile D-D' (fig. 6) is in the south-east corner of the study area (fig 1). The dominant features on this profile are the thin, continuous, relatively flat-lying reflectors indicative of fine-grained glaciolacustrine stratified drift. These beds extend to depths greater than $30 \mathrm{ft}$. Immediately below these reflectors, on the left side of the profile, are chaotic reflectors that may indicate the presence of coarse-grained material, such as till and (or) coarse sand and gravel. Loss of record below this point precluded interpretation of this unit; a test hole would be necessary to confirm the material types and depths. The strong, dark reflector on the left side of the profile, below the lost record (30- to 60 -ft-depth interval), is interpreted to be the bedrock surface.

On the right side of the record, between 0 and $150 \mathrm{~ns}$ (0- to 20 -ft-depth), the reflectors become subparallel and somewhat hummocky, in contrast to the fairly parallel and flat reflectors below and to the left (southeast). This pattern indicates that the sediment here is coarser than the sediments below and to the southeast. High-angle diffractions originating near the top of the profile on the right are from point reflectors, such as utility conduits crossing the road where the radar traverse was made. Low-angle diffractions in the lower parts of the profile probably represent radar reflections from trees or buildings near the survey lines.

\section{Seismic Refraction}

Five seismic-refraction surveys were done throughout the area to help interpret the GPR data. The locations of the five surveys and resulting profiles are shown in figure 2 . Geohydrologic sections interpreted from seismic-refraction data are shown in figures 7-8 and are described below.

Profile a-a' (fig. 7) is shown on figure 2. Perched ground water was found above lenses of fine-grained sediment during test drilling at test well NAW-242 (table 1). The depth to refusal was approximately $16 \mathrm{ft}$ at NAA-219 and approximately $33 \mathrm{ft}$ at NAW-24 (table 1). The depths predicted by seismic-refraction methods were similar to those determined from test drilling; however, depths determined from seismic-refraction data at the northeastern end of profile a-a' were slightly less than the depths determined from test drilling. GPR profile A-A' shows a similar bedrock profile and similar depths at the northeastern end of the line and illustrates the complex lithology at the site.

Profile b-b، (fig. 7) is approximately $1,000 \mathrm{ft}$ to the north of profile a-a' and on the northern side of Lyle Reed Brook (fig. 2). The depth to bedrock is approximately $40 \mathrm{ft}$ along most of the profile but decreases to less than $30 \mathrm{ft}$ below land surface near the southwestern end. The log of test well NAW-240 (fig. 2, table 1) shows refusal at $40 \mathrm{ft}$ below land surface.

Profile c-c' (fig. 7) is located in the center of the study area (fig. 2). The bedrock surface is 43 to $57 \mathrm{ft}$ deep. The log of test well M-6 (table 1) approximately $100 \mathrm{ft}$ from the northern end of the line shows refusal at $49.5 \mathrm{ft}$ below land surface.

Profile d-d' (fig. 8), in the southern part of the study area near Lyle Reed Brook (fig. 2), approximately $100 \mathrm{ft}$ southeast of the waste-disposal site, shows that the thickness of unconsolidated sediments is approximately $60 \mathrm{ft}$ over most of the profile. The water table is approximately 3 to $4 \mathrm{ft}$ below land surface on the western end, near Lyle Reed Brook, and $10 \mathrm{ft}$ below land surface on the east. These data are consistent with the data on the log of test well RFW-2B (table 1).

Profile e-e' (fig. 8) is about $1,000 \mathrm{ft}$ southeast of the waste-disposal site (fig. 2). This profile shows that the bedrock surface is approximately $80 \mathrm{ft}$ deep near the western end of the line and less than $60 \mathrm{ft}$ deep at the eastern end. The water table is 10 to $20 \mathrm{ft}$ deep.

\section{SUMMARY AND CONCLUSIONS}

Ground-penetrating radar and seismic-refraction surveys were completed near a former waste-disposal site in Nashua, New Hampshire. GPR profiles indicated lithologies in the glacial sediments and detected the bedrock surface in several profiles. The GPR profiles could not be used to delineate the water-table surface in many places because of the absence of a well-defined water-table reflector. In areas that yielded usable data, three distinct reflector signatures are evident. The first reflector signature is a thin, mostly horizontal and 


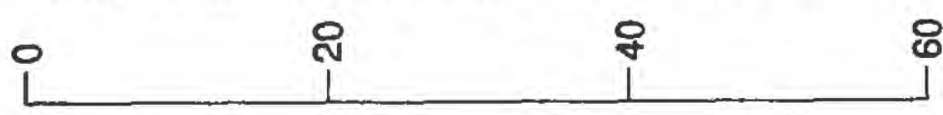

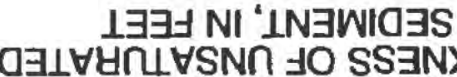

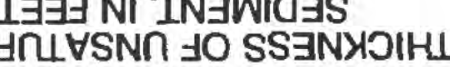

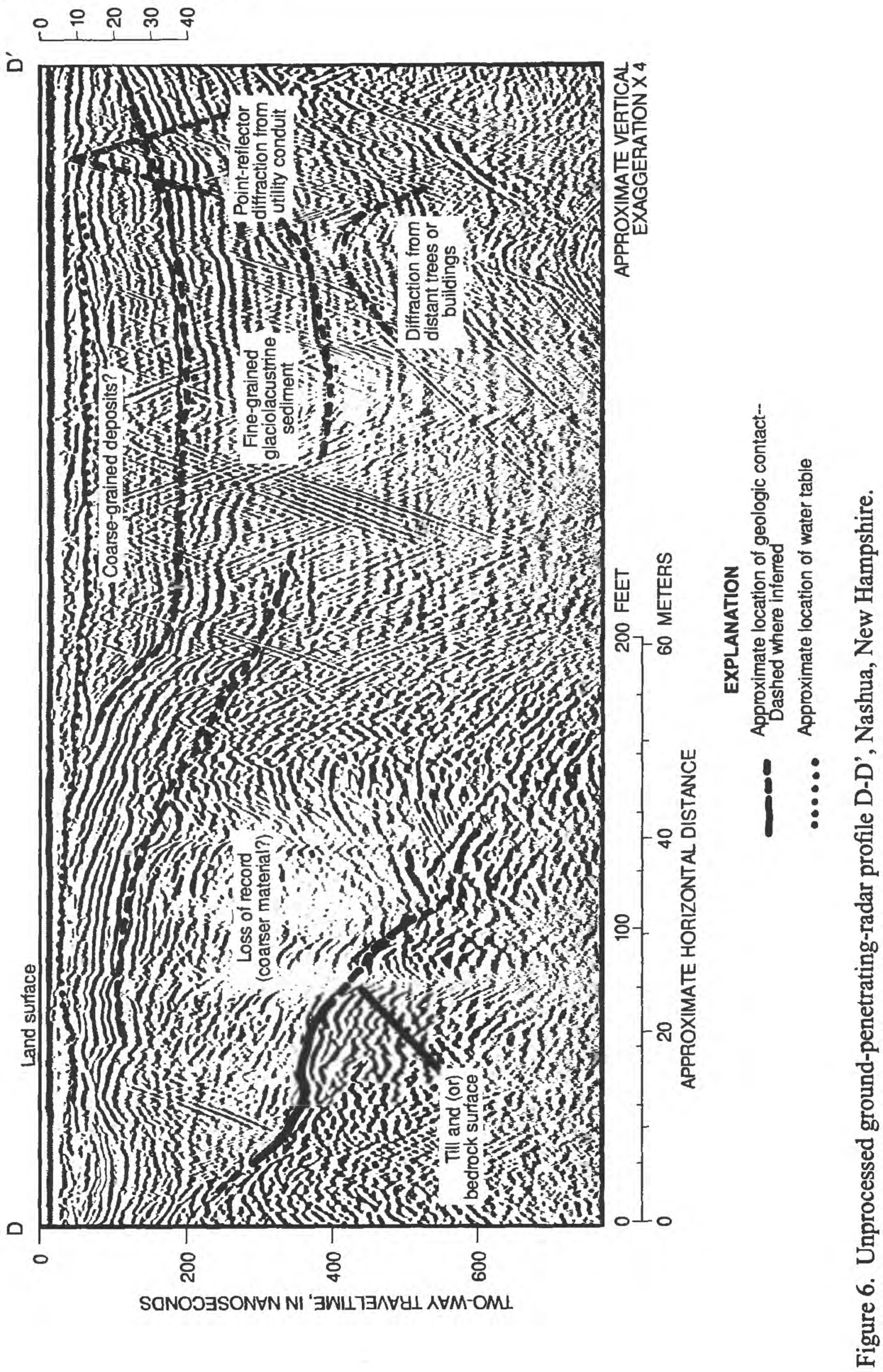




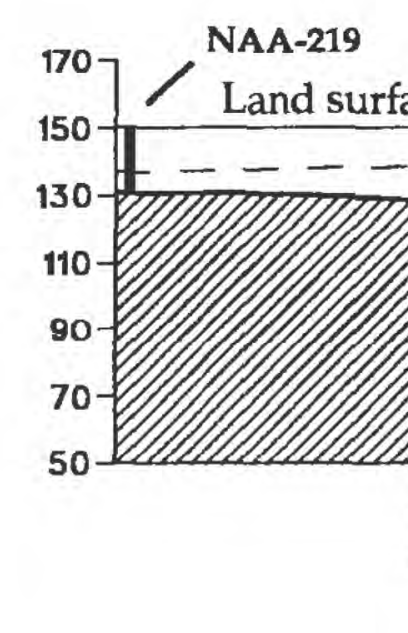

b

\section{FEET}

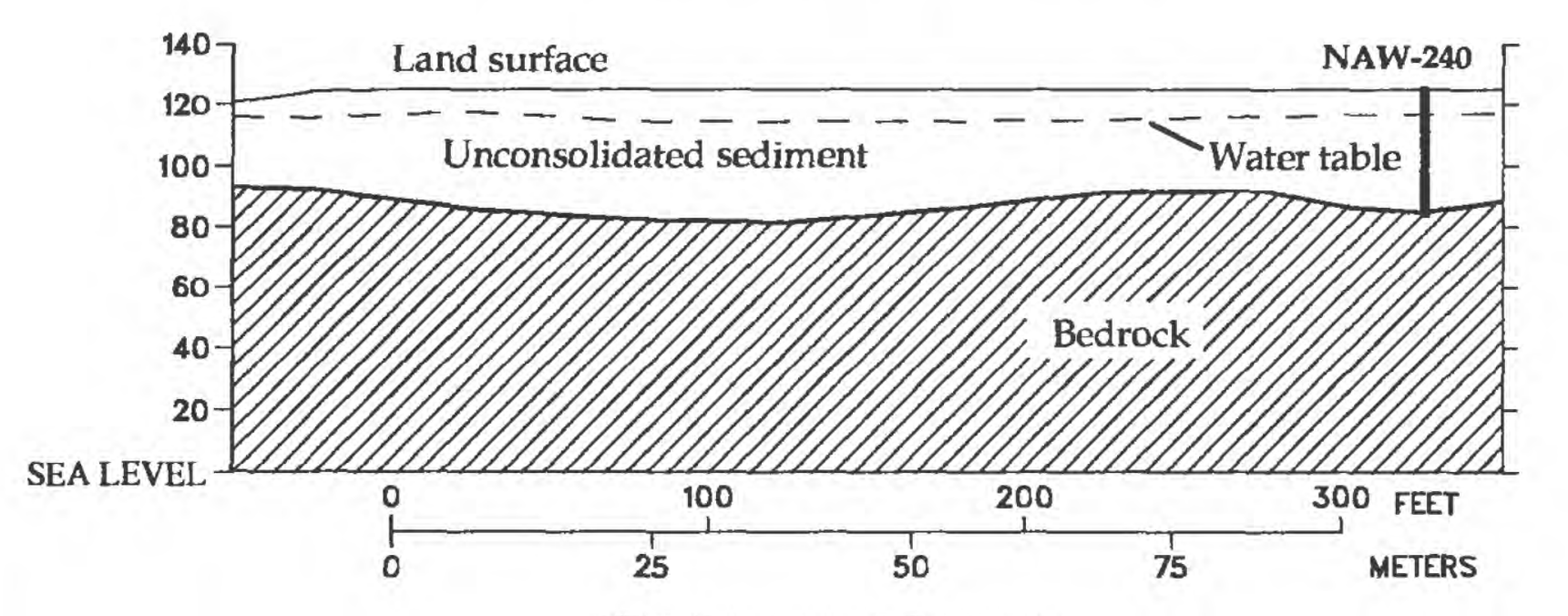

VERTICAL EXAGGERATTON X 1.0

C FEET
METERS

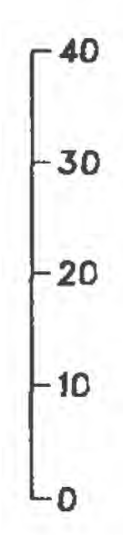

METERS

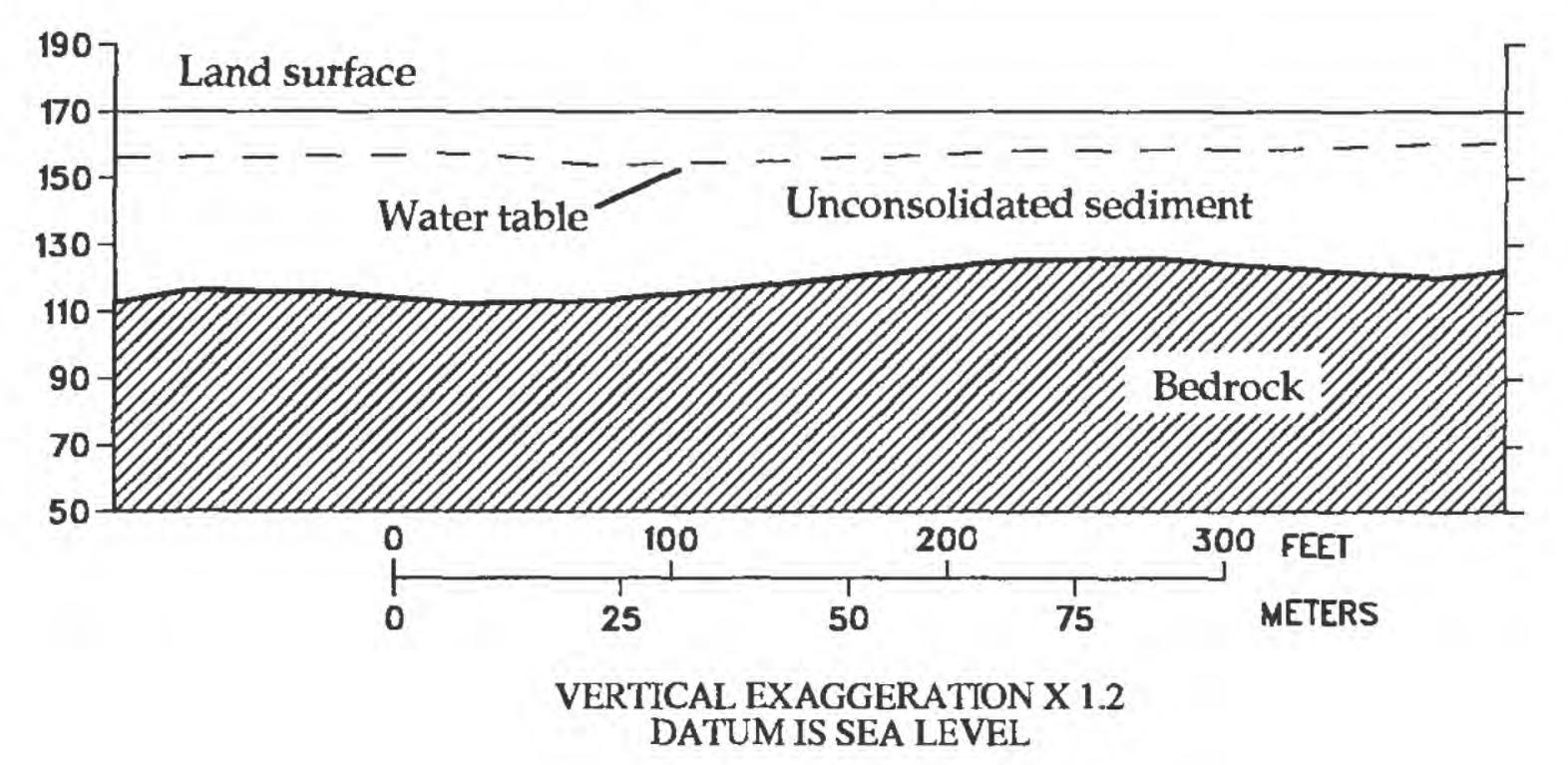

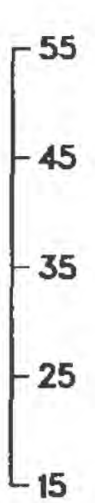

Figure 7. Geohydrologic sections interpreted from seismic-refraction data for profile a-a', b-b', c-c'. 


$\begin{array}{lll}\text { d } & \text { Gilson Road near Lyle Reed Brook } & \text { d' } \\ \text { METERS }\end{array}$

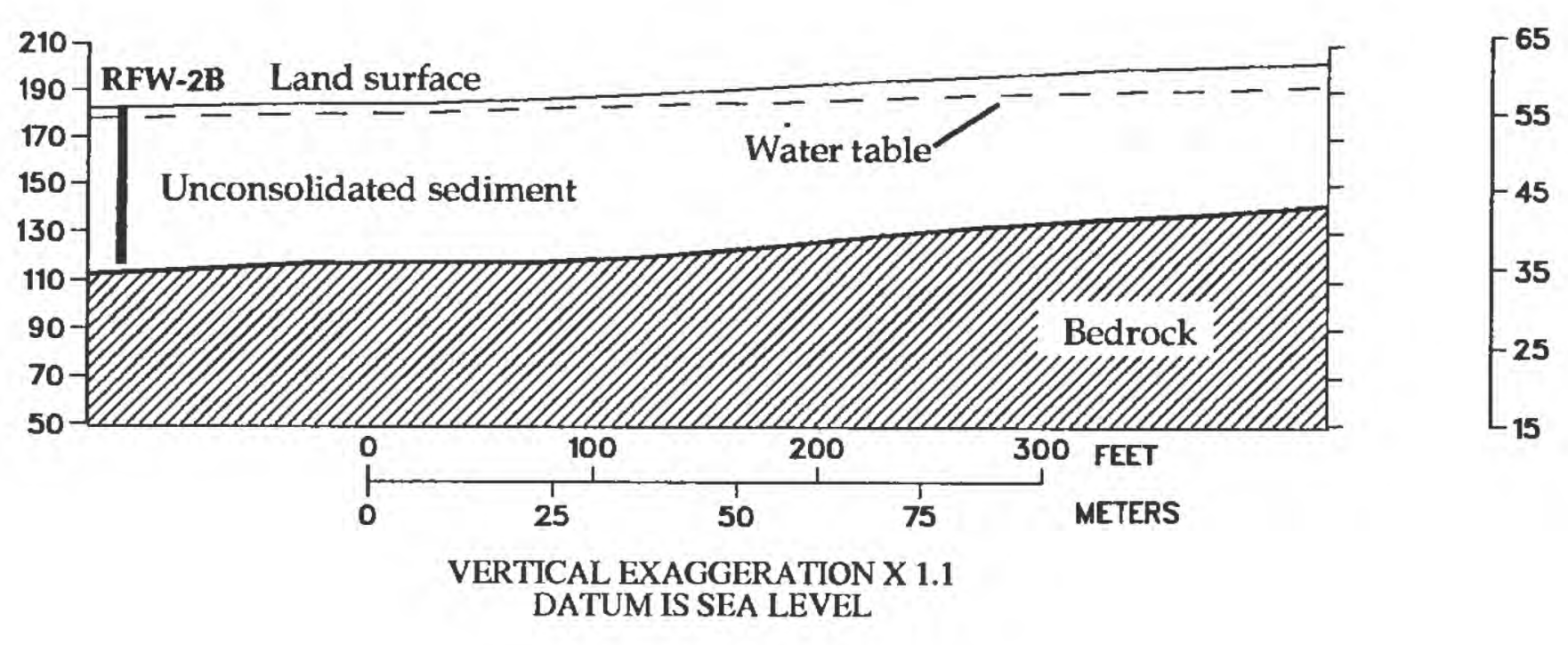

$\begin{array}{lll}\text { FEET } & \text { Gilson Road near Saturn Lane } & \mathrm{e}^{\prime} \text { METERS }\end{array}$

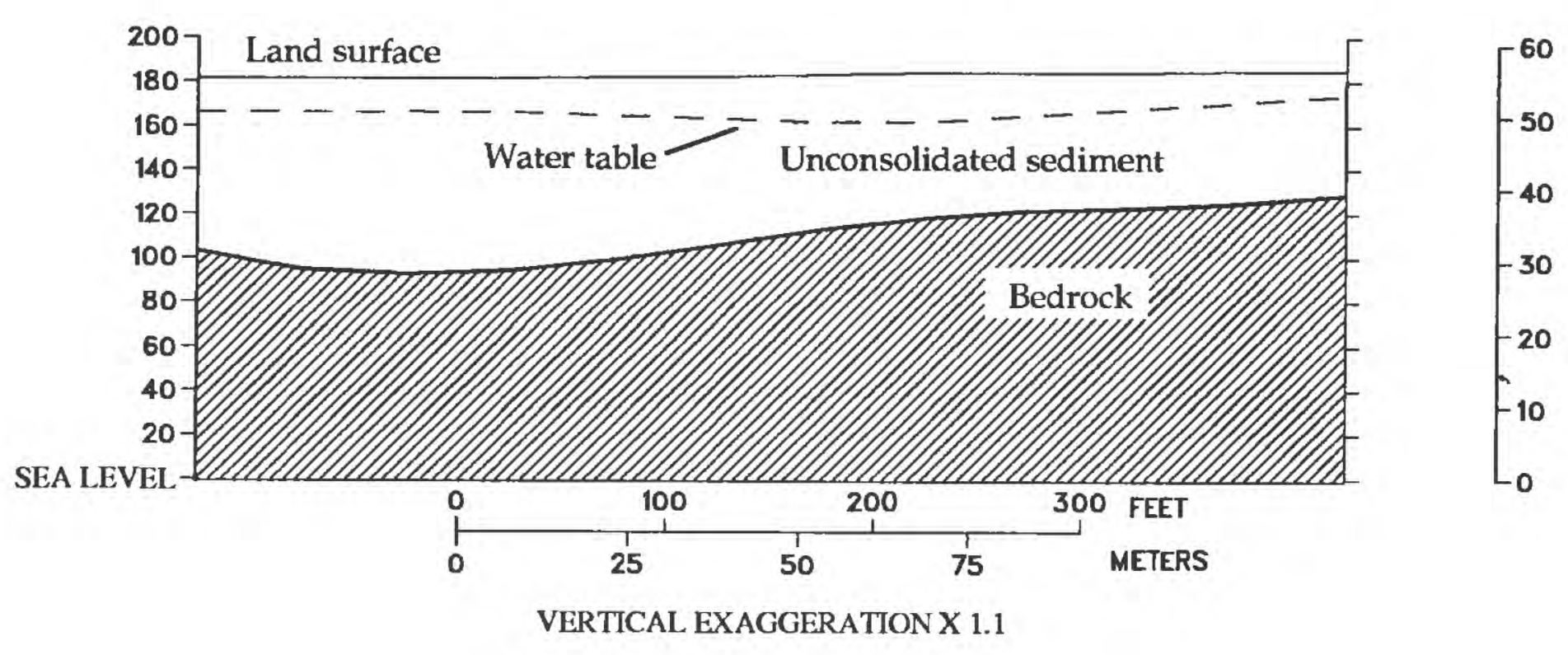

Figure 8. Geohydrologic sections interpreted from seismic-refraction data for profile d-d' and e-e'. 
coarse-grained sediment. The third reflector signature is a strong, two- to three-band reflector that generally underlies the other two types and represents the till and (or) bedrock surface.

The GPR profiles successfully identified glaciolacustrine sediments consisting of fine sand to clay that underlie much of the study area. This fine-grained unit generally prevented penetration of the radar signal to depths of more than $50 \mathrm{ft}$. Coarse-grained features identified in GPR records include outwash and deltaic deposits such as kame deltas. Till and coarse sand and gravel deposits were identified beneath fine-grained glaciolacustrine deposits in several of the profiles. Continuous bedrock reflectors were detected only to depths of $50 \mathrm{ft}$.

Five seismic-refraction profiles were completed in the area; they identified depths to the water table and to the bedrock surface. These depths were used to corroborate depths to reflectors shown by the GPR surveys; in most cases, depths of reflectors determined by GPR and seismic-refraction surveys were similar. Test drilling was completed at three sites to identify material types identified by the GPR and to corroborate depths to reflectors determined from the GPR and seismic-refraction surveys.

\section{SELECTED REFERENCES}

Ayotte, J.D.,1994, Use of ground-penetrating radar to determine the depositional environment of glacial deposits in southern New Hampshire in Bell, R.S., and Lepper, C.M., eds., Symposium of the application of geophysics to engineering and environmental problems, Boston, Mass., March 27-31, 1994: v. 2, p. 629-643.

Beres, Milan, Jr., and Haeni, F.P., 1991, Application of ground-penetrating-radar methods in hydrogeologic studies: Ground Water, v. 29, no. 3, p. 375-386.

Geophysical Survey Systems, Inc., 1974, Continuous subsurface profiling by impulse radar: Hudson, N.H., Geophysical Survey Systems, Inc., 20 p.

Haeni, F.P., 1988, Application of seismic-refraction techniques to hydrologic studies: U.S. Geological Survey Techniques of Water-Resources Investigations, book 2, chap. D2, $86 \mathrm{p}$.

Haeni, F.P., 1992, Use of ground-penetrating radar and continuous seismic-reflection profiling on surface-water bodies in environmental and engineering studies in Bell, R.S., ed., Symposium on the application of geophysics to engineering and environmental problems, Oak Brook,
Illinois, April 26-29, 1992, Proceedings: Golden, Colo., Society of Engineering and Mineral Exploration Geophysicists, p. 145-162.

Hansen, B.P., 1986, Exploration for areas suitable for ground-water development, Central Connecticut Valley Lowlands, Massachusetts: U.S. Geological Survey Water-Resources Investigations Report 84-4106, p. 25.

Johnson, D.G., 1992, Use of ground-penetrating radar for water-table mapping, Brewster and Harwich, Massachusetts: U.S. Geological Survey Water-Resources Investigations Report 90-4086, $27 \mathrm{p}$.

Koteff, Carl, 1970, Surficial geologic map of the Milford Quadrangle, Hillsborough County, New Hampshire: U.S. Geological Survey Geologic Quadrangle Map GQ-881, scale 1:62,500.

Koteff, Carl, 1976, Surficial geologic map of the Nashua North Quadrangle, Hillsborough and Rockingham Counties, New Hampshire: U.S. Geological Survey Geologic Quadrangle Map GQ-1290, scale 1:24,000.

Koteff, Carl and Volckmann, R.P., 1973, Surficial geologic map of the Pepperell Quadrangle, Middlesex County, Massachusetts, and Hillsborough County, New Hampshire: U.S. Geological Survey Geologic Quadrangle Map GQ-1118, scale 1:24,000.

Lieblich, D. A., Haeni, F. P., and Lane, J. W., Jr., 1992, Integrated use of surface geophysical methods to indicate subsurface fractures at Milford, New Hampshire: U.S. Geological Survey Water-Resources Investigations Report 92-4506. 38 p.

Lyons, J.B., Bothner, W.A., Moench, R.H., and Thompson, J.B., Jr., eds., 1986, Interim geologic map of New Hampshire: Concord, New Hampshire Department of Resources and Economic Development, Open File Report 86-1, scale 1:250,000.

Scott, J.H., Tibbetts, B.L., and Burdick, R.G., 1972, Computer analysis of seismic-refraction data: U.S. Bureau of Mines Report of Investigations RI 7595, 95 p.

Toppin, K.W., 1987, Hydrogeology of stratified-drift aquifers and water quality in the Nashua Regional Planning Commission Area, south-central New Hampshire: U.S. Geological Survey Water-Resources Investigations Report 86-4358, 45 p.

Weston, Roy F., Inc., 1989, Remedial program evaluation, Gilson Road site, Nashua, New Hampshire: Concord, N.H., v. 1, 135 p. 